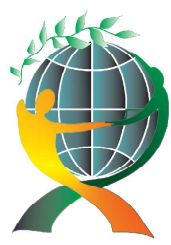

\author{
(online) $=$ ISSN $2285-3642$ \\ ISSN-L = $2285-3642$ \\ Journal of Economic Development, Environment and People \\ Volume 5, Issue 3, 2016
}

URL: http://jedep.spiruharet.ro

e-mail: office jedep@spiruharet.ro

\title{
Future Economy and Touristic Entrepreneurship
}

\author{
Viorica Jelev ${ }^{1}$ \\ ${ }^{1}$ Economic Sciences Faculty, Spiru Haret University
}

\begin{abstract}
Specialists claim that Eco-Bio-economy or social economy is the economy of future, in the service of human life by the rational use of environmental resources. The concept brings together in an integrated manner, according to the researchers, economy, ecology, biodiversity, biotechnologies and focuses on integrated sustainable development of the world. The new social economy, together with the corporate social responsibility joins a new multipolar world to a healthy environment by creative and innovative concepts that will ensure the sustainability of living in a sustainable manner. Doctors have added to this EcoBio-Economy concept a new one called One Health - a new integrated approach for human, animals and environment health state to that they should emphasize the importance of human behavior upon the planet biodiversity. Economer agents have mostly understood the importance of alarm signals drawn up by researchers on the destruction of the resources of the planet and adapted their business sites to the requirements of the green economy. A responsible business is also ecotourism that promotes a favourable travel for the surrounding environment. It requires accommodation on farms, in peasant houses, small rural hotels. The educational environment contributes to the trend planetary tourism, with the formation of new specialists with new knowledge, behaviors and consumers use formation of new characters, sensitive to environmental issues. This educational model is also promoted by Spiru Haret University, by creating the Master degree in tourism but also in environmental protection.
\end{abstract}

Keywords: eco-bio-economy, one-health, ecotourism, organic products, education

JEL Codes: A13, 115, 125, M21, O11, Q57, Z32

\section{Introduction}

1. The article aims at the development of the Eco-Bio-Economy problems of ecotourism and adds the new global concept of One Health, which refers to the integrated approach of animals and environment health, so that to emphasize the importance brought by the human behavior responsible for the planetary biodiversity.

2. Eco-Bio-Economy problem represents the economy of future, the economy in the benefit of human beings, considering the dependence of nature, man and animals, according to the laws of Creation. This concept developed the idea of ecotourism.

3. This article contains three parts: in the first part I explained the concept of Eco-Bio-Economy and the possible implications on living. The second part shows the way to start from the necessity to reduce the 


\author{
(online) = ISSN $2285-3642$ \\ ISSN-L = $2285-3642$ \\ Journal of Economic Development, Environment and People \\ Volume 5, Issue 2, 2016 \\ URL: http://jedep.spiruharet.ro \\ e-mail: office jedep@spiruharet.ro
}

quantities of wastes from the process of production, the manufacturing of some products and ecologic services that do not damage the environment becominga necessity to develop the companies for ecologic and bio-economy preoccupations including tourism. Here, we showed how the development of ecologic services market will lead to the ecologic infrastructure, which in its turn forms an ecologic industry, where ecotourism is included, passing graduallyto an increasing ecologic activity of the undertaken. The third part of the work is dedicated to the importance of education in producing changes inside of us but also around us, for coming back to nature, for the educational concerns for protecting, including the surrounding environment also including the ecologic tourism. In this trend Spiru Haret University is also integrated by creating Marketing and Touristic Management master degree and the one on the way of authorizing, Environment and Eco-Bio-Economy Management in One Healthcontext will form specialists, economists with solid knowledge in the field of tourism and environmental protection, those who will contribute to solve the problems of life pollution, rebuild the ecosystems altered by the anthropic impact and the most important thing is that they will become trainersfor new knowledge regarding nature and environment of Creation in general, subjected to aggression due to the modern lifestyle, especially directed to the irrational material consumption, contrary to the fundamental precepts of all religions of the world. The Earth is a gift of God that should be guarded and cultivated by a close connection between man and nature, for being inherited by future generations.

4. The basis of this article representedthe consultation and analysis of a large number of articles and books in Romanian and international specialized literature related to the topic of this article, with particular emphasis on issues such as:biotechnology, bio-economy, eco- economy, eco-bio-economy, ecotourism, environment and ecology, man and biosphere, sustainable development and diplomacy of bio-economy. The next paragraph is a brief review of the literature consulted.

The literature review on the subject matter related to it

There are currently a large number of scientific papers, articles, books, treatises, which analyze direct or indirect aspects such as bio-eco-economy, but also broader issues such as sustainable development, environmental protection, the relationship between man and the biosphere and environmental constraints and limited resources of an economy that often ignoring the limited capacity of the earth to bear an obvious over-exploitation of its resources. Eco-bio-economy can provide an answer to put into practice the concept of sustainable development and harmonize human activities with nature, including those that are closely related to food security, such as agriculture and agro-food economy as a whole. The National Strategy for Sustainable Development (SNDD 2013) with aspects related to its priorities of sustainable development aiming at the horizon of 2020 - 2030. In terms of the relationship economy - environment, the relationship of subordination must be from medium to economic and not vice versa (Brown 2001). If mankind hitherto considered that environment is a subfield of economics, natural resources being inexhaustible, Lester Brown shows that in realityeconomics must be a subdomain of the surroundings, environment where unfortunately natural resources are not inexhaustible. It is considered that the ideas in this paper must move to the forefront of global debates agenda. 


\author{
(online) = ISSN $2285-3642$ \\ ISSN-L = $2285-3642$ \\ Journal of Economic Development, Environment and People \\ Volume 5, Issue 3, 2016 \\ URL: http://jedep.spiruharet.ro \\ e-mail: office jedep@spiruharet.ro
}

A careful analysis of management organizations dealing with environmental protection and environmental policies and the importance of promoting a savings approach and concepts of activities in harmony with the environment is developed (Jelev, Brejea 2006). Academician Bogdan Alexandru promotes the concept of Eco-Bio-Economy in an original relationship with diplomacy (Bogdan Comsa 2011). Rabindranath Tagore wonderfully examines the concept of nature in the light of European and Oriental philosophies (Tagore 1922). James Lovelock takes a new look on life on Earth, emphasizing the idea that life and the Earthrepresentsa single being (Lovelock 1979). Air, water, oceans, ensure the existence of life on Earth in a complex, interrelated and interdependent, fragile and exposed exhaustion in the context of economic development chaotic, unsustainable, based on overuse of natural resources. This is why eco Bioeconomy is an approach and economic concept that can turn a chaotic development without concern for the environment, the sustainable one, thus giving to future generations a chance. The ecotourism arisen from the need to protect nature and the cultural traditions of nations, the increase of the level of education and awareness of tourists is necessary as a planet trend that brings substantial revenue to protect national parks and other protected areas but also the populations with income generating activities.

The article subject matter.

\title{
2. Introductory Ideas about Eco-Bio-Economy
}

Contributions to Nature and the collective mind is a whole of the living planet. If we are similar in shape, then we can say that we are part of the same family that includes mountains, seas, forests, birds and animals, stars and planets. Therefore, nature should be seen as our relative. All of us consist of the same material and the same spiritual essence and obey the same planet peace. We ought to keep the Creation that sustains our lives and abandons the irresponsible consumption the planet resources.

Consequently, researchers have developed the concept of Eco-Bio-Economy from the desire to live in harmony with our family, Nature.

Lester Brown is one of the pioneers of the environmental sustainable development concept and developed the concept of Eco-Economy namely that the green economy that emphasized the importance of ecology and environment protection, in the sustainable development of mankind [Brown, 2001]. The specialist states that the world economy cannot develop without considering the planet's ecological deficits, when we speak about our present and future. 40 years before the American scientist developed the concept of Eco-Economy, there was the Romanian scholar Nicholas Georgescu-Roegen, who launched the concept of Bio-Economy. In this concept the part of man in anthropogenic ecosystems is brought into questions. The author shows that where excessive consumption of raw materials planetary reserves are destabilized and endanger the future of the following generations [Bogdan, 2011].

The scientist sounded the alarm on the contradiction between the economic and unlimited growth and versus losses of planetary resources loss in the end. The proposed solution is in line with the economic decline physical law of entropy, needs to rebalance economic development by a comprehensive policy that respects the principles of biology.

The economy concept has evolved more than this, so that in the recent years the concept of Eco-BioEconomy has emerged by joining two visions. Academician Alexander Bogdan defines the new concept in the book, Eco-Bio-diplomacy: 


\author{
(online) $=$ ISSN $2285-3642$ \\ ISSN-L = $2285-3642$ \\ Journal of Economic Development, Environment and People \\ Volume 5, Issue 2, 2016 \\ URL: http://jedep.spiruharet.ro \\ e-mail: office jedep@spiruharet.ro
}

Eco-Bio-Economy is an economy of future in the service of human life by the rational use of environmental resources [Jelev, 2016d].

It promotes the sustainable development of mankind in all its forms by an economy sensitive to the needs of rational consumption of the planetary resources. This is a multipolar concept that promotes green nutrition and the integrated smart sustainable development of future.

Thus, we are witnessing today intelligent planetary tendency for a new consumer's behavior: we are more careful about what we eat and feed our food should be bio, what clothes we wear, the percentage of natural fibres should dominate material composition, the house we live, where the bulbs are ecologic and we should be careful with the unnecessary energy consumption. It is clear that we become the most responsible with our resources.

This new concept brings together in an integrator format economy, ecology, and biodiversity.

Here it was no longer to appear the Eco-Bio-Social Economy term, which leads directly to the above mentioned fields interwoven with socio-economic side of life, human resources and communities. These things cannot be achieved without a political decision that should be eco-bio-politics.

The new social economy must develop a new kind of entrepreneurship, where the economic actors should work in all sectors of society, changing attitudes and the consumer's behavior and utilization.

We are talking about the economy based on the contemporary biological revolution so that we can even call the Bio-Teconomia. This refers to all economic activities derived from scientific and research work focused on biotechnology. In other words, it is based on understanding mechanisms and processes at the genetic and molecular processes and their application in industrial or geographical landscape. Industries of agriculture, the chemical ones or energy, health are examples that could benefit from developments EcoBio-Economy applied [Jelev, 2016d].

In the national Eco-Bio-Economy plans we should discuss the measures and strategies to stimulate the research and development of crop production and agro-livestock, bio fuels and manufacturing processes of biological and medical treatments to replace traditional methods consumers of large natural resources.

In agriculture, in the context of the new economy, they must talk about permaculture, namely the nature based system that mimics the structural and functional ecosystem on natural cycles [Jelev, 2012]. We mention a permanent agriculture incorporating operational design, for example, the creation of terraces, raised layers. Water gardens, ponds, humus storage ditches storage the growth of aquatic plants, livestock breeding, fruit cultivation, the maintenance of Alpine pastures and cultivation of alpine and medicinal plants. In the forestry agriculture fruit trees and shrubs are integrated into the classic agriculture. Complementary tourism which is the type cross is not excluded either [Jelev, 2016d].

As conceptual derivatives, the Eco-Bio-management appears, i.e. green management, sustainable and innovative Eco-Bio-Business or Eco-Bio-Green-Business, for the user's satisfaction in the context of Eco-BioEconomy, which promotes Green power Intelligent Integrated Agricultural and Sustainable Development (Smart Integrated Sustainable Development) of future. 


\author{
(online) = ISSN $2285-3642$ \\ ISSN-L = $2285-3642$ \\ Journal of Economic Development, Environment and People \\ Volume 5, Issue 3, 2016 \\ URL: http://jedep.spiruharet.ro \\ e-mail: office jedep@spiruharet.ro
}

\title{
3. Eco-tourism Entrepreneurship
}

Unprecedented scale of the economic activity of people is one of the main causes of pollution which generally threaten the environment and life. At present, only $2-5 \%$ of the amount of primary materials is transformed into end products, the remaining ones $95-98 \%$ are transformed into waste. In today's society, people are mainly concerned with the results and less production of waste remaining after this production [Jelev 2006].

Starting with the need to reduce the amount of waste from the manufacturing process, manufacturing of products and provision of environmental services, which do not harm the environment, it becomes necessary for to develop companies with environmental concerns and bio-economy.

The eco-entrepreneurships is an activity of goods production and sale, works and provision of services for preventing damage to the environment and human health.

The first eco-entrepreneurship appeared in Central and Western Europe, where they formed the system of organic production principles and mechanisms able to address the overall environmental and economic issues. The department of technology, industrialization and economy in the UN Environmental Programmer (UNEP) has developed the strategy of organic production in 1989 and also adopted the Universal Declaration of Human Rights and the Environment [Jelev 2016c].

With increasing material welfare of the population, consumers demand for healthy food, green houses, with low energy appliances increase being more environmentally friendly and healthier for the body, holidays spent in fresh air and a healthy environment.

Thus, companies operating in tourism responded with increased interest of tourists for tours themed knowledge of nature and its protection, developing the concept of ecotourism also outlining and a new ethic of tourism aimed at transforming them into supporters of environmental preservation including natural and cultural environment.

Therefore there appeared bodies dealing with the extension of this concept among the communities. The most important structure is the International Ecotourism Society (TIES), set up in 1990 that aims to assist as many professional associations that make ecotourism a conservation and sustainable development. The non-profit association Ecotourism in Australia (EA) appeared in Australia in 1991, with the overall objective of being leaders in assisting ecotourism activities to become sustainable, economically viable and socially and culturally responsible. EA includes accommodation management companies, tour operators, travel agents, managers of protected areas, students and teachers, consultants, regional and local associations, the common goal is to develop the ecotourism industry. In 1998, the Japan Ecotourism Society - (JES), was set up in Japan with the vision that ecotourism is seen as an activity that requires a broader vision and practices a deeper understanding [Jelev 2016c].

Concerns are recorded in the area of ecotourism and also at the World Tourism Organization (WTO), the largest organization of travel. Implications for global ecotourism activity are also recorded by the United Nations by the United Nations Environment Programmer (UNEP).

The declaration by the United Nations of 2002 as the International Year of Ecotourism certified on one hand the scale of the ecotourism phenomenon acquired in recent years, and on the other hand emphasizes the concerns on the global understanding and adoption by all Member a position pro ecotourism .The most 


\author{
(online) = ISSN $2285-3642$ \\ ISSN-L = $2285-3642$ \\ Journal of Economic Development, Environment and People \\ Volume 5, Issue 2, 2016 \\ URL: http://jedep.spiruharet.ro \\ e-mail: office jedep@spiruharet.ro
}

important action linked to the International Year of Ecotourism World Ecotourism Summit was held in the Canadian city of Quebec 19-22 May 2002 in support of local Tourism Office and the Canadian Tourism Commission, under the aegis of the World Tourism Organization (WTO) and the Union for Nations Environment Programmer (UNEP)

[https://ro.wikipedia.org/wiki/Ecoturism\#Anul_2002_.E2.80.93_Anul_Interna.C8.9Bional_al_Ecoturismului]

In Romania, the National Institute for Research and Development in Tourism, INCDT, the National Strategy for Ecotourism Development was elaborated seeking a national and international eco-touristic experience, in the first phase, following the strategic plan of ecotourism, followed by the strategy achievement, implementation and monitoring actions in the second phase. Based on the consultations with policy makers in the field and after the SWOT analysis there were outlined some priorities in the development of Romanian tourism, underlying the action plan. These are:

-institutional and associative frame;

-infrastructure tourism and land management;

-education and awareness;

-development of human resources;

-development of affairs and local development;

-conservation and nature protection;

-Marketing and promotion.

As an organization in the country, the Association of Ecotourism in Romania (AER) functions by a partnership with tourism associations, NGOs and local development nature conservation, nature conservation projects and travel agencies. The innovative concept promoted by AER is to bring together public and private sectors into a partnership for nature conservation and sustainable tourism development [http://www.eco-romania.ro/ro/asociatia/despre-aer].

In Romania we have gone from promoting ecotourism, isolated products, made by parks administration or tour operators specialized in the development of the ecotourism destinations where to be offered an Eco touristic integrated product, born of the partnerships made by stakeholders (park administration, local government, local communities, private investors) and promoted both by associations of local ecotourism development efforts and central public administration contribution.

As a rule, these destinations could be developed on the skeleton of natural or national parks and biosphere reserves but ecotourism destinations can be created in other natural areas where the traditional lifestyle was kept unaltered (e.g. Natura 2000 sites).

The Yosemite National Park, the Natural Geopark Haţeg, the Danube Delta Biosphere Reserve, the Apuseni Natural Park, The Rodna Mountains National Park, the Maramures Mountains Natural Park, the Călimani National Park or the Macin Mountains National Park are just some of the possible ecotourism destinations.

In addition to the ecotourism where parks play a secondary role (e.g. Bucegi Natural Park, Domogled VAL Cerna), they can complement the established forms of tourism (mountain tourism, spa). In this sense, the question of providing new opportunities for leisure for these categories of tourists, increasing thereby 


\author{
(online) $=$ ISSN $2285-3642$ \\ ISSN-L = $2285-3642$ \\ Journal of Economic Development, Environment and People \\ Volume 5, Issue 3, 2016 \\ URL: http://jedep.spiruharet.ro \\ e-mail: office jedep@spiruharet.ro
}

leverage tourism infrastructure and provide a viable alternative for local sustainable development [http://www.mdrl.ro/_document/tourism/studii_strategii/ecoturism_faza2.pdf].

\title{
4. The role of school at present: the formation of new consumer's conduct and utilization, character formation, the transfer secured by experience
}

Due to the importance given to this topic in the world, Spiru Haret University is implementing a master's degree in tourism, entitled Marketing and Tourism Management but also to be accredited, a Master Program Management and Eco-Bio-Economy in the context One Health. It will take place in the Faculty of Economic Sciences and will aim to form economists with a broad vision on economic development and sustainable development of the country, taking into account the implications on environment, health living.

With the mission of education and scientific research undertaken by its goals, master programs fall into coordinates overall mission Spiru Haret University and the department organizer, namely the Faculty of Economics, training of future specialists, scroll continuing education programs and research in tourism and economically.

Future specialists, economists with deep knowledge in the field of tourism and environmental protection, ethics environment, will help solve the problems of pollution life, restore ecosystems damaged by human impact and more important, they will become trainers of new consciousness on nature and environment. Creation is generally subjected to aggression because of modern lifestyle, preference for material consumption, contrary to the fundamental precepts of all world religions [R. Tagore in 1922]. The earth is a gift from God to be cherished and cultivated, by a close link between man and nature, to be bequeathed to future generations.

\section{Conclusion}

Each work presents the new Eco-bio-economy and One Health concepts, the last one representing a unitary approach of the surrounding environment and health problems in a unitary concept: man, animal and environment. It is pointed out the interdependence between the environment factors and health, emphasizing the importance of eco-bio-economy for passing across from a sustainable development concordant with the environment and social problems.

Specialists affirm that Eco-Bio-Economy is the economy of future for the benefit of people's life by the national utilization of the environment resources.

In the opinion of researchers the concept in an integrant form reunites economy, ecology, biodiversity, biotechnologies. The new social economy together with the corporatist social responsibility joins into a multipolar new world for a healthy environment by Creative and innovating concepts that will ensure the sustainability of living in a sustainable way. As we showed above, doctors added to this Eco-Bio-Economy concept a new one. It is about the integrating approach of man and animals' health state and environment. 


\author{
(online) = ISSN $2285-3642$ \\ ISSN-L = $2285-3642$ \\ Journal of Economic Development, Environment and People \\ Volume 5, Issue 2, 2016 \\ URL: http://jedep.spiruharet.ro \\ e-mail: office jedep@spiruharet.ro
}

So that it should emphasize the importance brought to the human behaviour responsible for the biodiversity of the planet.

Most of the economic agents have understood the importance of alarm signals shown by researches regarding the destruction of the resources of the planet and adapted business to the requirements of the green economy.

Consequently, in tourism the ecotourism idea appeared desiring to focalise itself.

In order to obtain economic profits on long terms on condition to maintain the ecologic balance, the economic development must agree with the host populations necessities and aspirations for ensuring a decrease of the negative impact upon local visited community and contribute to the preservation of culture and local traditions and of course to contribute in a positive way at the protection of the national areas.

The involvement of these new approaches, but especially taking into consideration the entire eco-bioeconomy and health idea in "One Health" concept is multiple supposing deep concept transformations is thinking and approaching all human activities, with benefic effects over the surrounding environment and planet's health considered in the biosphere ensemble and of all living creatures, including man. .

Education must contribute to the new planetary trend by forming new knowledge and conception and utilization behavior, new characters sensitive to the problems of the surrounding environmental that supports life.

Spiru Haret University brings a substantial contribution in forming specialists in tourism and Eco-BioEconomy by two master degree courses: Marketing and Tourism Management and Environmental Management and Eco-Bio- Economics in One Health context. The necessity to form new graduates in the field of tourism and environment management and eco-bio-economy, referring that the health of Earth biodiversity resulted after to studies carried out by our group on the evolution offer and demand in the work market of Romania as well as the demand of labor force in our country and the European space.

The deep connection among nature, its protection, religion, human and animal health, but also education should become a study subject at all educational levels. Only in this way we will transform ourselves into real lovers and defenders of the surrounding environment and nature, who recognizes in it the supreme harmony to ennoble our life [Tagore 1922].

We have single chance to get out of the crisis the whole mankind is involved: to choose a real spiritual rebirth. In other words, to live in harmony with God, with us ourselves with our fellow creatures and with nature. Not accidentally Jesus said: "I am the Way, Truth and Life". We were shown the truth, the way and now it's our turn to answer at this calling.

\title{
5. References (This is "Header 1" style)
}

[1] Bogdan T.Al., Comșa D., (2011), Eco-Bio-Diplomația, Editura AOSR, Bucuresti

[2] Brown L., (2001), Eco-economie : crearea unei economii pentru planeta noastra, Editura Tehnică

[3] Jelev V., (2012), Ecomarketing, Editura Fundația România de Mâine

[4] Jelev V., (2005a), Politica agricolă comunitară și economia agroalimentară, Editura Universitatea din Oradea

[5] Jelev V.,(2005b), Economie agricolă și agroalimentară.Note de curs, Editura Universitatea din Oradea 


\author{
(online) $=$ ISSN $2285-3642$ \\ ISSN-L = 2285 - 3642 \\ Journal of Economic Development, Environment and People \\ Volume 5, Issue 3, 2016 \\ URL: http://jedep.spiruharet.ro \\ e-mail: office jedep@spiruharet.ro
}

[6] Jelev V.,(2016c), Social Economy and Ecotourism, LANDSCAPES: PERCEPTION, KNOWLEDGE, AWARENESS and ACTION,International Symposium, 24 iunie

[7] Jelev V., (2016d), Eco-bio-economia sau economia viitorului in context one health, Conferinta Nationala a cadrelor didactice, Facultatea de Siinte Economice, 19-20 May

[8] Jelev I., Breja R., (2006), Sisteme aplicate de management ale mediului înconjurător, Editura Universitatea din Oradea

[9] Lovelock J. (1979), Gaia: A New Look at Life, Oxford University Press, New York

[10] Tagore R. (1922), Sadhana - Calea Desavarsirii, Cultura Nationala, Bucuresti

[11] SNDD (2013), Strategia Națională pentru Dezvoltare Durabilă, la orizontul anilor 2013-2020-2030 în http://www.mmediu.ro/beta/domenii/dezvoltare-durabila/strategia-nationala-a-romaniei-2013-2020-2030/

[12] MADR, 2016a, Dinamica-operatorilor-si-a-suprafetelor-in-agricultura-ecologica http://www.madr.ro/agriculturaecologica/dinamica-operatorilor-si-a-suprafetelor-in-agricultura-ecologica.html

[13] MADR, 2016b, Promovare-produselor-agricole http://www.madr.ro/promovare-produseloragricole.htmIAgricultura-ecologica http://www.madr.ro/agricultura-ecologica.html

[14] MADR, 2016c, Comunicări organisme de inspecție și certificare în http://www.madr.ro/agriculturaecologica/organisme-de-inspectie-si-certificare.html

[15] MMEOH, 2016, Raportul final Masterat MMEOH, Facultatea de Științe Economice, Spiru Haret, 2016

[16] http://www.cunoastelumea.ro/c-tin-dulcan-neurolog-viata-noastra-pe-pamant-este-doar-o-mica-parte-din-ceeace-avem-de-trait/

[17] www.mdrl.ro/_documente/turism/studii_strategii/ecoturism_faza2.pdf

[18] http://www.eco-romania.ro/ro/asociatia/despre-aer

[19] https://ro.wikipedia.org/wiki/Ecoturism\#Anul_2002_.E2.80.93_Anul_Interna.C8.9Bional_al_Ecoturismului

[20] http://www.mdrl.ro/_documente/turism/studii_strategii/masterplan_partea1.pdf 